Dermatology 2009;218:172-174

DOI: $\underline{10.1159 / 000182255}$

\section{Lupus Vulgaris: A New Look at an Old Symptom - The Lupoma Observed with Dermoscopy}

\author{
Marcella Brasielloa, Iris Zalaudekc, Gerardo Ferrara ${ }^{b}$, \\ Jean-Yves Gourhant ${ }^{\mathrm{d}}$, Patrizio Capoluongo a , Paolo Roma ${ }^{\mathrm{a}}$, \\ Giuseppe Argenziano ${ }^{\mathrm{a}}$ \\ ${ }^{a}$ Department of Dermatology, Second University of

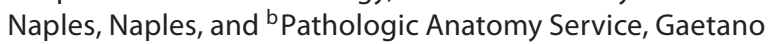 \\ Rummo General Hospital, Benevento, Italy; ' ${ }^{\mathrm{D}}$ Department \\ of Dermatology, Medical University of Graz, Graz, Austria; \\ ${ }^{\mathrm{d} D e r m a t o l o g y}$ Center, Nemours, Paris, France
}

\section{Key Words}

Dermatoscopy $\cdot$ Lupus $\cdot$ Tuberculosis

Lupus vulgaris (LV) is the most frequent form of cutaneous tuberculosis in industrialized countries, which occurs in patients previously sensitized to Mycobacterium tuberculosis [1]. Cutaneous lesions result from a spread of tuberculosis bacteria from an endogenous reservoir to the skin or rarely from exogenous sources (biologic liquids) such as infectious droplets. LV consists of a solitary reddish-brown papule located on the head/neck area that coalesces to form a plaque with serpiginous borders, which typically progresses by peripheral extension and central healing, resulting in central atrophy and scarring. Despite these typical findings, the list of differential diagnoses is long, making the correct diagnosis challenging [2]. Furthermore, unusual clinical manifestations including atypical features, multiple lesions or involvement of other body areas may cause further diagnostic difficulties $[3,4]$. Not surprisingly, the diagnosis of LV should be based on a correlation of clinical and histopathologic features, the latter represented by typical tuberculoid granulomas containing Langhans-type giant cells in the absence of caseous necrosis. For some equivocal cases, additional laboratory tests such as special stains or cultures might be helpful [5].

A correct diagnosis and an adequate treatment are crucial because LV, if left untreated, carries the risk of local destruction or development of malignant skin tumors including squamous cell carcinoma and, less commonly, basal cell carcinoma and cutaneous sarcoma [6-10]. Dermoscopy is a noninvasive diagnostic tool allowing the visualization of pigmented and vascular structures that are not visible to the unaided eye [11]. Traditionally, this technique has been used for the evaluation of skin tumors, but more recently dermoscopy has been discovered to assist also the clinical diagnosis of common inflammatory or infectious skin diseases [12-14].

We recently observed 3 patients affected by LV and exhibiting repetitive dermoscopic features that may aid the clinical diagnosis of LV [14].

\section{Case Reports}

The lesions were observed on the left earlobe of a 48-year-old man (patient 1), on the nose of a 33-year-old woman (patient 2), and on the eyebrow and scalp of a 65-year-old man (patient 3). All lesions appeared at least 2 years before the first dermatologic consultation. Patient 1 presented with a solitary, succulent, reddish and ill-defined nodule $1.5 \mathrm{~cm}$ in diameter adjacent to an area of atrophy on the left earlobe (fig. 1A). A clinical differential diagnosis between LV and nodular basal cell carcinoma or squamous cell carcinoma was made. By contrast, the lesions in patients 2 and 3 appeared as erythematous scaly, roundish plaques with accentuated borders, with no central atrophy or scarring (fig. 1B-D). In the latter patients, the primary clinical differential diagnosis included seborrheic eczema, discoid lupus, tinea and superficial basal cell carcinoma. Biopsy of all lesions was performed and revealed histopathologic features suggestive of LV.

Dermoscopic examination of all lesions revealed fine focused telangiectasias on a typical yellow to golden-colored background. In addition, some milia-like cysts and whitish reticular streaks were observed (fig. 2).

\section{Comment}

Our preliminary observations are far too scanty to reach any conclusions about the impact of dermoscopy in diagnosing LV, but the pattern seen in these four lesions seems worth further discussion. It should be noted that none of the observed features per se is highly specific, but it is actually their combination that appeared to us typical of LV. Focused telangiectasias have recently been described in superficial basal cell carcinoma, but in the latter, vessels are typically associated with central whitish to reddish structureless areas and/or multiple small ulcerations [15-17]. Milia-like cysts, particularly if multiple and associated with hairpin vessels, are highly suggestive of seborrheic keratosis. Whitish streaks may occur in a number of melanocytic and nonmelanocytic tumors, but again, their combination with additional features will allow a specific diagnosis in most cases $[15,16]$.

I.Z. is currently supported by the Elise Richter Program (V9-B05) of the Austrian Science Fund (FWF).

\section{KARGER}

(C) 2008 S. Karger AG, Basel

Fax +41613061234 E-Mail karger@karger.ch www.karger.com 

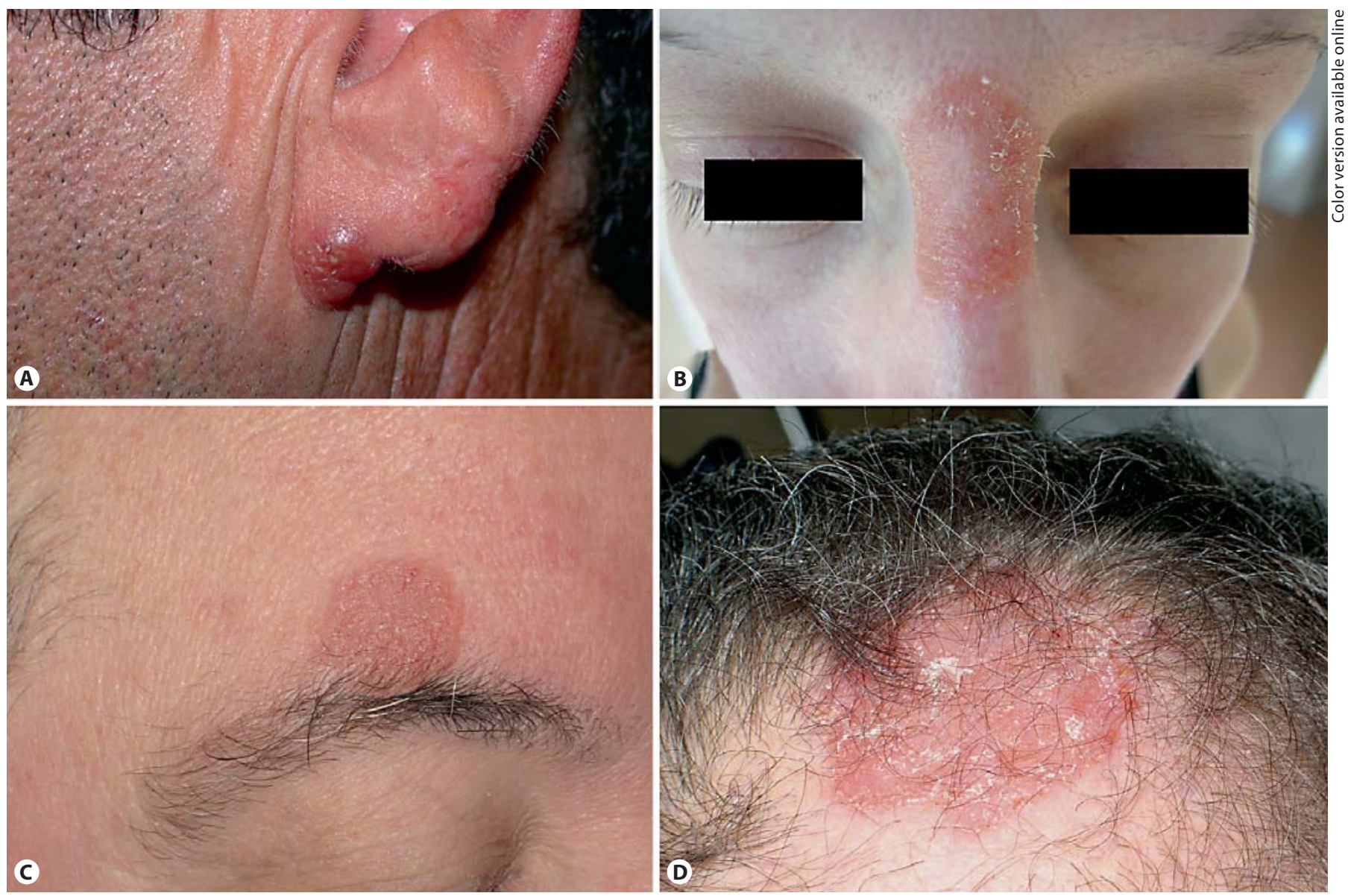

Fig. 1. Clinical images of LV located on the earlobe of a 48-year-old man (A), the nose of a 33-year-old woman (B) and on the eyebrow (C) and scalp (D) of a 65-year-old man.

LV may mimic clinically various inflammatory/infectious skin disorders such as discoid lupus, eczema, and tinea, to name just a few. However, the latter conditions usually lack pigmentation. In our view, the most typical dermoscopic finding in LV is the yellow to golden-colored background, which is similar to the so-called 'apple-jelly' sign seen under traditional diascopy [18].

In conclusion, our preliminary observation suggests that LV reveals repetitive dermoscopic features that may aid the clinical diagnosis, but this observation requires further confirmation on a larger series of cases.

\section{References}

1 Wozniacka A, Schwartz RA, Sysa-Jedrzejowska A, Borun M, Arkuszewska C: Lupus vulgaris: report of two cases. Int J Dermatol 2005;44: 299-301.

-2 Bartralot R, Garcia-Patos V, Sitjas D, Rodriguez-Cano L, Mollet J, Marti-Casabona N, Coll P, Castellas A, Pujol RM: Clinical patterns of cutaneous non-tuberculous mycobacterial infections. Br J Dermatol $2005 ; 152: 727-734$
Senol M, Ozean A, Mizrak B, Turgut AC, Karaca S, Kocer H: A case of lupus vulgaris with unusual location. J Dermatol 2003;30:566-569.

4 Khandpur S, Reddy BS: Lupus vulgaris: unusual presentations over the face. J Eur Acad Dermatol Venereol 2003;17:706-710.

5 Marcoval J, Servitje O, Moreno A, Jucglà A, Peyrí J: Lupus vulgaris: clinical, hystophatologic, and bacteriologic study of 10 cases. J Am Acad Dermatol 1992;26:404-407.

-6 Ceylan C, Gerceker B, Ozdemir F, Kazandi A: Delayed diagnosis in a case of lupus vulgaris with unusual location. J Dermatol 2004;31:5659.

7 Brauninger W, Bork K, Hoede N: Tumor-like lupus vulgaris. Hautarzt 1981;32:321-323.

8 Gooptu C, Marks N, Thomas J, James MP: Squamous cell carcinoma associated with lupus vulgaris. Clin Exp Dermatol 1998;23:99-102.

9 Yerushalmi J, Grunwald MH, Halevy DH, Avinoach I, Halevy S: Lupus vulgaris complicated by metastatic squamous cell carcinoma. Int J Dermatol 1998;37:934-935.

10 Salodkar A, Khare AK, Khullar R, Singhi MK, Ahmed K, Kachhawa D: Squamous cell carcinoma complicating lupus vulgaris. Indian J Dermatol 1992;37:14-15.

11 Kittler H, Pehamberger H, Wolff K, Binder M: Diagnostic accuracy of dermoscopy. Lancet Oncol 2002;3:159-185. 

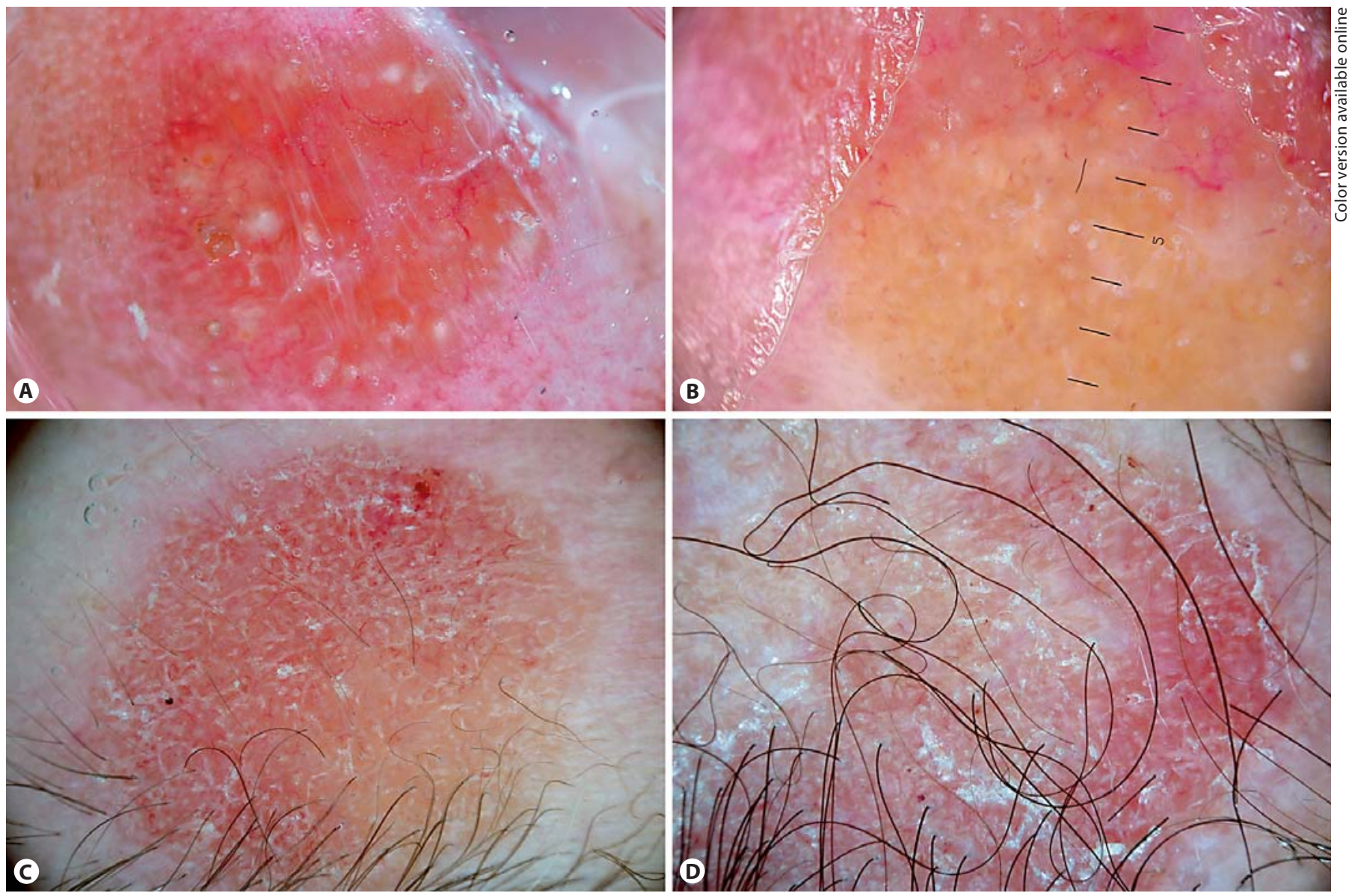

Fig. 2. Dermoscopic images of the lesions as shown in figure 1. In all cases, fine focused telangiectasias on a yellow to golden-colored background can be seen. Additionally, some milia-like cysts can be seen in A and B, whereas whitish reticular streaks are well visible in $\mathbf{C}$ and $\mathbf{D}$.

12 Argenziano G, Soyer HP, Chimenti S, Talamini R, Corona R, Sera F, Binder M, Cerroni L, De Rosa G, Ferrara G, Hofmann-Wellenhof R, Landthaler M, Menzies SW, Pehamberger H, Piccolo D, Rabinovitz HS, Schiffner R, Staibano S, Stolz W, Bartenjev I, Blum A, Braun R, Cabo H, Carli P, De Giorgi V, Fleming MG, Grichnik JM, Grin CM, Halpern AC, Johr R, Katz B, Kenet RO, Kittler H, Kreusch J, Malvehy J, Mazzocchetti G, Oliviero M, Ozdemir F, Peris K, Perotti R, Perusquia A, Pizzichetta MA, Puig S, Rao B, Rubegni P, Saida T, Scalvenzi M, Seidenari S, Stanganelli I, Tanaka M, Westerhoff K, Wolf IH, Braun-Falco O, Kerl H, Nishikawa T, Wolff K, Kopf AW: Dermoscopy of pigmented skin lesions: results of a consensus meeting via the Internet. J Am Acad Dermatol 2003;48:679-693.

13 Zalaudek I, Argenziano G, Di Stefani A, Ferrara G, Marghoob AA, Hofmann-Wellenhof R, Soyer HP, Braun R, Kerl H: Dermoscopy in general dermatology. Dermatology 2006;212:7-18.

14 Zalaudek I, Giacomel J, Cabo H, Di Stefani A, Ferrara G, HofmannWellenhof R, Malvehy J, Puig S, Stolz W, Argenziano G: Entodermoscopy: a new tool for diagnosing skin infections and infestations. Dermatology 2008;216:14-23.

15 Kreusch JF: Vascular patterns in skin tumors. Clin Dermatol 2002;20 248-254.
16 Argenziano G, Zalaudek I, Corona R, Sera F, Cicale L, Petrillo G, Ruocco E, Hofmann-Wellenhof R, Soyer HP: Vascular structures in skin tumors: a dermoscopy study. Arch Dermatol 2004;140:1485-1489.

17 Giacomel J, Zalaudek I: Dermoscopy of superficial basal cell carcinoma. Dermatol Surg 2005;31:1710-1713.

18 Lupus vulgaris; in Braun-Falco O, Plewig G, Wolff HH: Dermatologie und Venerologie, ed 4, revised. Berlin, Springer, 1996, pp 227-228.

Iris Zalaudek, MD

Department of Dermatology, Medical University of Graz

Auenbruggerplatz 8, AT-8036 Graz (Austria)

Tel. +4367633 28269, Fax +39081566 6675

E-Mail iris.zalaudek@meduni-graz.at 